EETP Vol. 16, 2021, №. 1(59)

ISSN 1896-2327 / e-ISSN 2353-7787

DOI: 10.35765/eetp.2021.1659.11

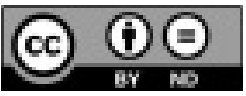

Nadesłano: 28.11.2020

Zaakceptowano: 16.02 .2020

Sugerowane cytowanie: Pusz S. (2021). Edukacja kulturowa uczniów klas I-III szkoły podstawowej w świetle podstawy programowej i podręcznika "Szkolni przyjaciele”, „Edukacja Elementarna w Teorii i Praktyce", vol. 16, nr 1(59), s. 151-164.

DOI: 10.35765/eetp.2021.1659.11

\title{
Sławomira Pusz
}

ORCID 0000-0003-3273-7974

Uniwersytet Rzeszowski

\section{Edukacja kulturowa uczniów klas I-III szkoły podstawowej w świetle podstawy programowej i podręcznika Szkolni przyjaciele}

\section{Cultural Education of Early School Students in the Light of the Core Curriculum and the Textbook School Friends}

\section{SŁOWA KLUCZE ABSTRAKT}

edukacja kulturowa, wychowanie, kultura, edukacja wczesnoszkolna, podstawa programowa, podręcznik
Celem artykułu jest analiza „Podstawy programowej kształcenia ogólnego dla szkoły podstawowej”, obowiązującej od września 2017 roku, oraz podręczników edukacji wczesnoszkolnej serii wydawniczej WSiP Szkolni przyjaciele pod kątem wychowania do kultury. Skoncentrowano się na wartościach i normach społecznych jako wiodącego elementu w oddziaływaniach wychowawczych szkoły, ale uwzględniono także zakres kultury materialnej i symbolicznej zawartych w powyższych źródłach. Zastosowana analiza dokumentów w przypadku podstawy programowej obejmuje swym zakresem cele kształcenia w szkole podstawowej oraz cele i treści kształcenia w klasach I-III. Badanie dotyczy systemu wartości jakie autorzy podręcznika pragną przekazać kolejnym pokoleniom i postaw, które uważają za najważniejsze. Uwzględniono koncepcję ukazywania przez podręczniki rzeczywistości w jej różnych wymiarach - społecznym, materialnym, politycznym; mając na uwadze wiek i możliwości percepcyjne odbiorców tych treści. W wyniku badań stwierdzono, że w porównaniu do zarzutów pojawiających się względem poprzednio obowiązującej podstawy programowej, ta zawiera odniesienia do ponadczasowych wartości dobra, prawdy i piękna, przytoczone są konkretne wartości odnoszące się 
do patriotyzmu, wychowania obywatelskiego, mniejszy nacisk kładą autorzy na postawy twórcze uczniów i poznanie dorobku w zakresie muzyki czy plastyki. Autorzy podręcznika położyli największy nacisk na wpajanie uczniom społecznych norm i wartości obowiązujących w szkole i rodzinie. Obraz świata prezentowany w podręcznikach jest nieco wyidealizowany i stereotypowy.

\section{KEYWORDS ABSTRACT}

cultural education, upbringing, culture, early education, core curriculum, textbook
The aim of the article is to analyze the Core curriculum for comprehensive education in primary schools valid since September 2017, and early education textbooks of the WSiP publishing series: School Friends, in terms of cultural education. The author focused on the analysis of social values and norms as leading elements in the educational impact of the school, but also on the range of tangible and symbolic aspects of culture included in the above sources. In case of the core curriculum, the analysis of the documents includes the objectives of primary school education as well as the objectives and contents of education in grades 1-3. The study concerns the system of values that the authors of the textbooks want to pass on to future generations, and the attitudes they consider the most important. It also refers to the way in which the textbooks show reality in its various dimensions: social, material and political, taking into account the age and perceptual abilities of the recipients. According to the research results, in comparison to the accusations made against the previously applicable core curriculum, this one contains references to timeless values of good, truth and beauty, and to some specific values related to patriotism and civic education. Also, the authors of the current core curriculum place less emphasis on the creative attitudes of students and their knowledge of human achievements in the field of music or art. The authors of the textbooks emphasize teaching students social norms and values important both at school and in the family. The image of the world presented in the textbooks is somewhat idealized and stereotypical.

\section{Wprowadzenie}

Obecnie w kulturze można wyróżnić wielość kierunków, nurtów i znaczeń rozumienia pojęcia „pluralizm kulturowy”. Interpretowany jako zjawisko pozytywne i pożądane, wśród odbiorców, szczególnie młodych, może wywoływać chaos poznawczy i problemy interpretacyjne oraz trudności z wyborem właściwej ścieżki ułatwiającej poruszanie się w różnych obszarach kultury. Dlatego ważna jest edukacja i wychowawcza rola szkoły jako przewodnika w procesie wchodzenia dzieci i młodzieży w społeczny dorobek kulturowy. 


\section{Analiza pojęć}

Edukacja to jedno z podstawowych pojęć pedagogiki o znaczeniu szerokim i niejednorodnym. Najczęściej jest określana jako „ogół oddziaływań służących formowaniu się (zmienianiu, rozwijaniu) zdolności życiowych człowieka” (Kurdybacha 2011: 25). $\mathrm{Na}$ edukację składa się wychowanie i kształcenie. Wychowanie powszechnie jest definiowane jako celowe i planowe wywieranie wpływu i powodowanie zmian w rozwoju wychowanka, ale może być rozumiane jako wspomaganie rozwoju wychowanka w samorealizacji i pracy nad sobą (Łobocki 2005: 32-41). „Kształcenie to system działań zmierzających do tego, aby uczącej się jednostce umożliwić poznanie świata, przygotowanie się do zmieniania świata i ukształtowanie własnej osobowości”(Kurdybacha 2011: 26). Zatem wychowanie oddziałuje na motywy, potrzeby, emocje, odniesienia do innych ludzi; natomiast kształcenie dotyczy sfery poznawczej jednostki, oczywiście pośrednio także wpływa na stosunek człowieka do rzeczywistości (por. Kurdybacha 2011: 26). Mieczysław Łobocki obok wychowania operuje też pojęciem „inkulturacja”, rozumianym jako „proces wchodzenia przez jednostkę w życie kulturalne danego społeczeństwa, czyli wrastanie w charakterystyczną dla niego kulturę (Łobocki 2005: 45). Autor przytacza też różne definicje inkulturacji, m.in. najkrótszą Friedricha Krona „uczenie się kultury”. Na przestrzeni dziejów zmieniały się ideały wychowania od antycznego „calocagatii” po „człowieka pracy socjalistycznej” w Polsce Ludowej, ewaluowały także cele kształcenia i wychowania. Powstawały różne nurty i kierunki w pedagogice, które skutkowały pojawianiem się określonych dyskursów od funkcjonalistyczno-behawioralnego po konstruktywistyczny czy krytyczno-emancypacyjny (por. Klus-Stańska 2009: 25-75). Warunkowały one odmienne wizje wychowania i edukacji oraz podejście do kształcenia.

Kultura - pojęcie stosowane w języku potocznym oraz naukach humanistycznych i społecznych, wywodzi się z łacińskiego terminu cultura odnoszącego się do uprawy roli, ale już Cycero stosował je jako „kultura duszy”, rozumiejąc jako oddziaływania mające na celu polepszenie stanu początkowego, tak jak działania ogrodnika wpływają pozytywnie na jakość plonów. Pojęcie to ewaluowało na przestrzeni wieków, zmieniając swoje pierwotne znaczenia; rozumiane było jako doskonalenie człowieka w sferze moralnej i umysłowej, ale też jako całościowy dorobek ludzkości. Kulturę łączy się ze wszystkim, co człowiek nabywa w swym doświadczeniu społecznym, co przyswaja na drodze uczenia się od innych członków danej grupy (por. Jabłońska 2019: 132-133).

Funkcjonuje wiele definicji kultury, które $\mathrm{w}$ zależności od dziedziny nauki (filozofia, socjologia, antropologia) czy nurtu, jaki reprezentują poszczególni badacze, kładą nacisk na inne aspekty czy elementy znaczeniowe. W języku potocznym pojęcie to także jest obecne, ale rozumiane jest nieco inaczej i ma silne zabarwienie 
wartościujące. Definicja przyjęta na przez UNESCO na Zgromadzeniu w Meksyku określa kulturę jako

„zespół cech wyróżniających o charakterze duchowym i materialnym, intelektualnym i afektywnym, które właściwe są społeczeństwu i grupie społecznej. (...) Obejmuje sposoby życia i wytwarzania dóbr materialnych i symbolicznych, systemy wartości, wierzenia i poglądy. Z uwagi na estetyczną rolę sztuk pięknych i literatury kultura stanowi podstawę żywotnych sił każdego społeczeństwa i narzędzie jego trwałości i odnowy" (Wojnar 2000: 127).

O tym, jak ważna jest kultura dla pedagogiki, może świadczyć fakt powstania na przełomie XIX i XX wieku nurtu pedagogika kultury. Jednakże początków wspólnoty kultury i wychowania należy doszukiwać się w starożytnej Grecji, gdzie powstało pojęcie paideia, rozumiane jako budowanie osobowości w oparciu o dobra kultury i wartości. Celowe i świadome wprowadzanie dzieci i młodzieży w świat idei, wartości, humanizmu i refleksja nad efektywnością tych działań to istota pedagogiki kultury (Gajda 2006: 15-17). Pojęcia „wychowanie” i „kultura” są nierozerwalnie ze sobą powiązane. Człowiek tworzy kulturę, a kultura wpływa na wszystkie sfery osobowości człowieka, dlatego funkcjonują różne określenia obrazujące te zależności, np. wychowania do kultury, przez kulturę. Jarosław Gara stosuje określenie kultura wychowania, a Wincenty Okoń wychowanie w kulturze (por. Korzeniecka-Bonar 2017). Wielość określeń i ich ciężar gatunkowy rodzi dylematy, które z nich jest najtrafniejsze i najpełniej oddaje istotę i wagę ich wzajemnych uwarunkowań. Niezaprzeczalnym pozostaje fakt, że nie można oddzielić wychowania od kultury, bo jak stwierdził socjolog kultury Andrzej Tyszka „kultura jest w pierwszym rzędzie konfiguracją wartości, więcej nawet, jest afirmacją i kultem wartości, jest ich społecznym wyborem i indywidualnym przeżyciem" (Bednarek, Repsch 2004: 7).

W obszarach pedagogiki i kultury funkcjonują dwa zbliżone do siebie pojęcia „edukacja kulturalna” i „edukacja kulturowa”. To pierwsze, chyba starsze historycznie, korzeniami sięga lat 80. XX wieku i prac Bogdana Suchodolskiego i Ireny Wojnar, która podkreślając znaczenie wartości tkwiących w kulturze, jej rozumienie, odbiór i przeżywanie, określa istotę działań edukacyjnych jako „kształtowanie kultury w ludziach”. Suchodolski uwypuklał w kontaktach jednostki ze światem kultury nie tylko jej poznanie, zrozumienie i przeżywanie, ale także aktywny udział w tworzeniu kultury, kreatywność i zaangażowanie wszystkich ludzi w różnych działaniach kulturowych (por. Jankowski 2003: 923-929). Katarzyna Olbrycht wyróżniła trzy znaczenia pojęcia „edukacja kulturalna”, z których ostatni obejmuje szeroki i różnorodny zakres działań w zakresie kultury i wielość podmiotów; dotyczy mecenatu państwa nad kulturą i przyjęcie określonej polityki edukacyjnej. Takie rozumienie tego pojęcia jest bliskie pojęciu „edukacji kulturowej”. 
Edukacja kulturowa jest pojęciem szerokim, obejmującym swym zakresem działania edukacyjne dotyczące zarówno kultury artystycznej (tzw. kultury wysokiej), jak i życia codziennego, sfery symbolicznej i materialnej. Edukacja kulturowa łączy się z przekazywaniem młodemu pokoleniu kodów kulturowych, wiedzy o dorobku kultury, historii i tradycji, a co za tym idzie - budowaniem tożsamości społecznej. Celem edukacji kulturowej jest

(...) pełnienie roli pośrednika pomiędzy twórcą a odbiorcą, pomiędzy dziełem a jego widzem, poszerzanie wrażliwości artystycznej, zwiększanie kompetencji, przygotowanie do „czytania tekstów kultury”, wytwarzanie potrzeby obcowania z kulturą, a co za tym idzie rozwój społeczeństwa przygotowanego do społecznego współżycia (Koschany, Skórzyńska (red) 2014: 69-71).

Edukacja kulturowa to spotkanie jednostki z dobrami kultury i przejmowanie przez jednostkę wartości w nich zawartych. Łączy się ona z poznaniem, zrozumieniem i przejęciem przez młode pokolenie wzorów kulturowych (Encyklopedia pedagogiczna XXI wieku. Suplement: 610-612), które teoretycy dzielą na trzy grupy: kulturę materialną (bytu, cywilizacji), symboliczną (niematerialną, duchowa) i społeczną (socjetalna). W zakresie kultury materialnej znajdują się działania i osiągnięcia techniki, produkty służące zaspokajaniu potrzeb bytowych. Do kultury symbolicznej zalicza się sferę związaną z wartościami i przeżyciami duchowymi spełniającymi funkcje estetyczne, ludyczne, poznawcze. Najszerzej analizowana jest trzecia grupa, związana z wartościami i normami, ich przekazywaniem i tworzeniem relacji społecznych pod wpływem obowiązujących w danej grupie wzorów zachowań i zasad postępowania.

Edukacja kulturowa łączy się z określeniem znaczących wytworów powstałych na przestrzeni dziejów, dzieł, norm, zasad, systemu wartości, które kolejne pokolenia powinny poznać i przyswoić, czyli tak zwanego kanonu kultury. Wanda Zwinogrodzka (2014) w trakcie kongresu „Polska Wielki Projekt 2014” przytoczyła trzy definicje rozumienia tego pojęcia. Debata dotyczyła twórców kultury, ale ujęcie kanonu jako pewną wypadkową między tradycją narodową a dyskursem polityczny można odnieść także do systemu kształcenia. Tak rozumiany kanon kultury rzutuje na reformy w edukacji, a w rezultacie znajdująe swoje odzwierciedlenie w zmianach w zakresie podstawy programowej i programów.

\section{Refleksje nad szkolną edukacją kulturalna - odniesienia do literatury}

Każda reforma szkolnictwa niesie ze sobą mniej lub bardziej rewolucyjne zmiany w zakresie programów kształcenia, dotyczące również kanonu kultury. Cele kształcenia są odzwierciedleniem systemu wartości preferowanego przez politykę oświatową 
i nie zawsze odpowiadają na wyzwania świata współczesnego i potrzeby poszczególnych jednostek. Andrzej Bogaj (1998) cytuje poglądy i tezy Jerome’a Brunera „nic nie jest wolne od kultury”, a jednostka interpretując i oceniając rzeczywistość, odnosi się do zbudowanego w umyśle kanonu zasad, norm, wartości, czyli wyposażenia kulturowego społeczności, w której wzrastała. Autor postuluje zmianę podejścia do edukacji, a szansę na zmiany upatruje w odejściu od szkoły tradycyjnej nastawionej na transmisję wiedzy, na rzecz edukacji wspierającej jednostkę w budowaniu systemu wartości i norm życia społecznego, kształtowania postaw humanistycznych. Poprawy jakości edukacji upatruje w założeniach podstawy programowej z 1997 toku, z której wynika, że szkoła będzie bardziej ukierunkowana na jednostkę i jej indywidualność, na budowanie kompetencji, a nie wiedzy, odchodząca od rywalizacji na rzecz współpracy, nastawiona na integrację i budowanie całościowego obrazu świata, większą autonomię jednostki i jej wspieranie. Bogaj dostrzega jednak zdecydowanie więcej wad niż zalet: krytycznie odnosi się do celów zawartych w podstawie programowej z 1997 roku jako ogólnikowych, nieprecyzyjnych i nieprzystających do zmieniających się warunków. Podkreśla brak sprecyzowanego kanonu kształcenia ogólnego oraz uzasadnienia dla pięciu etapów kształcenia ogólnego, a także neguje kompetencje, jakie uczniowie powinni osiągnąć na poszczególnych etapach kształcenia. Wśród nich zdecydowanie brakuje kompetencji związanych z wychowaniem do takich wartości jak: tolerancja, wiara w siebie, dążenie do samorozwoju, wrażliwość na krzywdę, solidarność, uczciwość, troska o sprawy publiczne, patriotyzm czy też związanych z etosem pracy. Bogaj zarzuca autorom brak standardów kształcenia i nadal dominujący nacisk na posiadanie wiedzy.

Anna Pikała (2014) analizuje podstawę programową z 2012 roku, rozpatrując edukację kulturalną na wszystkich szczeblach kształcenia - od przedszkola po szkoły ponadgimnazjalne. Edukację kulturalną zawęża do kultury symbolicznej odnoszącej się do sfery świadomości, przeżyć, wartości. Autorka, powołując się na Danielę Rusakowską, stwierdza, że reformatorzy systemu edukacji i twórcy programów edukację kulturalną rozumieją jako edukację artystyczną, czyli uwzględniającą literaturę, teatr, muzykę, plastykę itp. W artykule Pikała koncentruje się na edukacji muzycznej i plastycznej. Dzięki temu, że autorka rozdziela w swej analizie poszczególne etapy edukacji, w niniejszym artykule odnoszę się wyłącznie do zagadnień dotyczących klas I-III. Badaczka docenia łączenie aktywności muzycznej z plastyczną, ruchową, taneczną jako czynnika rzutującego na ogólny rozwój dzieci, podkreśla również wartość rozwijania uzdolnień artystycznych. Wskazuje, że uczeń uczestniczy w percepcji i recepcji sztuki, poznaje wybrane dzieła architektury, sztuk plastycznych i inne należące do polskiego i europejskiego dziedzictwa kultury. Edukacja muzyczna obejmuje ekspresję wokalną, ruchowo-taneczną, instrumentalną i twórczą, kształcenie słuchu muzycznego, rozumienie i przeżywanie muzyki, rozwijanie nawyków czynnego uczestniczenia 
w kulturze muzycznej. Autorka odnosi się także do Rozporządzeń MEN z 2009 i ME$\mathrm{NiS}$ z 2002 roku w sprawie ramowych planów nauczania w szkołach publicznych, aprobując stosowanie muzyki w celach relaksacyjnych.

Edukacja kulturowa w klasach I-III łączy się z uświadomieniem uczniom szerokiego zakresu osiągnięć ludzkości w zakresie norm i wartości, wytworów działań ludzi, które są nośnikami tych wartości, oraz norm i zasad regulujących zachowanie w różnych grupach społecznych; umożliwia przybliżanie im wartości ponadczasowych, ukazywanie przykładów właściwego postępowania jako efektu przyswojenia i stosowania obowiązujących norm społecznych. Na tym etapie edukacji przebiega wstępna inicjacja kulturowa, będąca początkiem drogi do poznania dorobku kulturowego i wartości preferowanych w społeczeństwie.

\section{Edukacja kulturowa na I etapie edukacyjnym w Podstawie programowej kształcenia ogólnego dla szkoły podstawowej}

Aktualna podstawa obowiązująca od września 2017 roku, spośród 13 celów kształcenia zarówno pierwszy „wprowadzanie uczniów w świat wartości, w tym ofiarności, współpracy, solidarności, altruizmu, patriotyzmu i szacunku dla tradycji, wskazywanie wzorców postępowania i budowanie relacji społecznych", jak i ostatni odnosi do wartości. Przy czym ostatni jest ogólnikiem i brak w nim skonkretyzowania zakresu wartości „ukierunkowanie ucznia ku wartościom”. Analizując I etap edukacji w szkole podstawowej, już w głównym celu edukacji wczesnoszkolnej podkreśla się znaczenie ponadczasowych, absolutnych wartości „odkrywania własnych możliwości, sensu działania oraz gromadzenie doświadczeń na drodze prowadzącej do dobra, prawdy i piękna”. W zadaniach szkoły dla tego okresu edukacji uwypuklone zostało „poznanie wartości i norm społecznych, (...), oraz rozwijanie zachowań wynikających z tych wartości, (...) poznanie kultury narodowej, odbiór sztuki i potrzebę jej tworzenia, (...) zaspokajanie potrzeb poznania kultur innych narodów”. Przy analizie zakresu treści poszczególnych edukacji dziwi fakt, że w edukacji polonistycznej prawie wszystkie osiągnięcia ucznia dotyczą konkretnych umiejętności i odnoszą się raczej do strony technicznej (recytuje wiersze, czyta...); jest tylko wzmianka o empatii i szacunku dla rozmówcy w komunikacji werbalnej. Brakuje informacji o elementarnym poznaniu

Podstawa programowa wychowania przedszkolnego i ksztatcenia ogólnego dla szkoty podstawowej z komentarzem. Wychowanie przedszkolne i edukacja wczesnoszkolna (2017). Wszystkie cytaty w tej części artykułu pochodzą z tego dokumentu, ale w związku z funkcjonowaniem wersji elektronicznej, używane będą skróty zapisu przyjęte w praktyce nauczycielskiej w postaci: I-XIII rodzaj edukacji, 1-8 zakres kompetencji, 1)-9) odniesienia do konkretnych działań ucznia (dotyczy treści kształcenia). 
literackiego kanonu kultury. Sporo odniesień do systemu wartości, jakie należy wpajać młodemu pokoleniu, można znaleźć w edukacji społecznej. Są wymienione wartości takie jak: „godność, honor, powściągliwość, sprawiedliwość, obowiązkowość, pomoc, życzliwość, uznanie" (III.1.4). Wychowanie obywatelskie łączy się ze stosowaniem pojęć „porozumienie”, „umowa”, uczestnictwem w wyborach samorządu klasowego i szkolnego, poznaniem działalności stowarzyszeń pomocy chorym i niepełnosprawnym dzieciom, organizacji ekologicznych czy państw i Unii Europejskiej. W podstawie programowej jest bardzo dużo zagadnień związanych z kształtowaniem postaw patriotycznych, od znajomości ciekawostek historycznych dotyczących regionu i kraju, legend dotyczących powstania Polski, jej godła, barw, tradycji, ale jest też zaskakujące stwierdzenie uczeń: „rozpoznaje mundur wojskowy” (III.2.2). Są odwołania do znajomości zwyczajów i tradycji polskich, ale także do fundamentalnych wynalazków w historii, które istotnie wpłynęły na funkcjonowanie ludzi np. „cyfry rzymskie i arabskie, papier, mydło, instrumenty muzyczne” (III.2.6). Także współczesny dorobek kultury technicznej znalazł odzwierciedlenie $\mathrm{w}$ analizowanym dokumencie $\mathrm{w}$ postaci „bezpieczeństwa podczas korzystania z urządzeń cyfrowych (...) stosuje zasady netykiety" (IV.2.13). Podstawa programowa precyzuje, jakie postacie z historii Polski uczniowie kończący edukację wczesnoszkolną powinni poznać, spośród 7 reprezentantów są aż 4 kobiety: królowa Jadwiga, M. Skłodowska-Curie, Wanda Rutkiewicz, oraz gen. Elżbieta Zawadzka „Zo” (III.2.7). Zdziwienie może budzić fakt, że królów Polski reprezentuje Stefan Batory, a należałoby się raczej spodziewać założycieli państwowości Mieszka I czy Bolesława Chrobrego. Do obowiązkowego kanonu wielkich Polaków autorzy zaliczyli Jana Pawła II i Mikołaja Kopernika; zdecydowanie brakuje przynajmniej jednego reprezentanta twórców kultury. Szacunek i miłość do ojczyzny autorzy pragną kształtować nie tylko poprzez budowanie wiedzy o przeszłości i geografii Polski, ale także poprzez poznanie przez uczniów sukcesów Polski na arenie międzynarodowej, np. w dyscyplinach sportowych, sferze artystycznej lub gospodarczej. W założeniach analizowanego dokumentu jest również odniesienie do kształcenia uczniów pochodzących z mniejszości narodowych i etnicznych, którzy zobligowani są do poznawania rodzimego języka i kultury, z której się wywodzą (XI.1.-XI.4).

W ramach edukacji plastycznej uczniowie edukacji wczesnoszkolnej poznają wytwory materialnego dziedzictwa kulturowego „dziedziny sztuk plastycznych malarstwo, rzeźbę, dziedziny sztuki użytkowej np. meblarstwo, tkactwo (...) architekturę, grafikę komputerową, (...) gatunki dzieł malarskich i graficznych: pejzaż, portret (...)" (V.3.1)-3.3). W zakresie ekspresji twórczej uczniów, oprócz odniesień do strony technicznej (rysuje, maluje, modeluje itp.), jest też odwołanie do norm i wartości ważnych w wychowaniu do kultury, związanych z wyrażaniem własnych przeżyć i emocji poprzez prace plastyczne. Edukacja muzyczna wprowadza uczniów klas I-III w sferę 
niematerialnego dziedzictwa kulturowego, przybliżając im świat dźwięków i uwrażliwiając na jego piękno. Ucząc słuchania muzyki, nauczyciel powinien dostosować jej percepcję do możliwości psychofizycznych dziecka, łącząc ją z aktywnością ruchową. Autorzy podkreślają także potrzebę ekspresji muzycznej w zakresie śpiewu, ruchu czy gry na instrumentach „gra (...) własne schematy rytmiczne (VII.4.1). Zgodnie z założeniami, uczniowie powinni także opanować kod muzyczny i grę na wybranym instrumencie: „dzwonkach, ksylofonie, flecie podłużnym, flażolecie” (VIII.4.7). Edukacja językowa w zakresie języka obcego już od I klasy jest wprowadzeniem uczniów w świat kultury europejskiej.

\section{Analiza podręczników}

Analizując cykl podręczników Szkolni przyjaciele pod kątem zawartych w nich kodów kulturowych, przyjęto perspektywę Ewy Zalewskiej odejścia od analizy konwencjonalnej na rzecz prezentowanego w nim obrazu świata (Zalewska 2009: 516-529). Autorka zadaje pytania o kryteria, jakimi kierują się autorzy podręczników edukacji wczesnoszkolnej przy wyborze „reprezentatywnej wiedzy”, którą uczniowie są zobligowani przyswoić, oraz czy uczeń, który poznaje różnorodność świata poprzez media, zaakceptuje jednostronny przekaz zawarty w podręczniku. Zalewska analizując podręczniki obowiązujące po reformie w 1999 roku i dostosowane do ówczesnej podstawy programowej, pokazuje ich jednostronność w ukazywaniu uczniom rzeczywistości kulturowej i społecznej. W podręcznikach występuje „powtórne kodowanie wiedzy społecznej i kulturowej w specyficzny dydaktyczny sposób" (Zalewska 2009: 512). Obraz świata w nich prezentowany jest wyidealizowany, politycznie poprawny - brak w nim ukazywania aktualnych problemów, np. biedy, bezrobocia, wykluczenia. Wizja świata dorosłych obrazuje, w jaki sposób autorzy postrzegają możliwości percepcyjne ucznia. Autorka odwołuje się do koncepcji Doroty Klus-Stańskiej „dyskursów dziecięcego uczenia się", w których istotne są dwa kryteria: zaufanie do dziecięcych kompetencji oraz zgoda na decyzyjność dziecka (zarówno pierwsze, jak i drugie jest w małym stopniu zauważalne w przedmiocie analizy). Tradycyjny szkolny podręcznik postrzegany jest jako źródło prawomocnej i jedynie słusznej wiedzy o świecie i budujący fałszywe przekonanie, że samo obcowanie z tą książką pozwoli uczniowi zinternalizować postawy pożądane społecznie, które są prezentowane w podręczniku.

Podobne poglądy można także znaleźć w książce Aleksandry Szyller (2018a: 40-45), która szeroko analizuje podręczniki edukacji wczesnoszkolnej, także pod kątem reprezentowanego w nich obrazu świata. Autorka rozpatrując problem inności, dochodzi do wniosku, że prezentowany uczniom świat jest jednowymiarowy, podkreślane są różnice etniczne i kulturowe, a przedstawiciele innych nacji są 
ukazani w sposób stereotypowy (Eskimos w igloo). Brakuje informacji o najbliższych sąsiadach Polski, a wskazywane przez autorów różnice między ludźmi dotyczą jednego kręgu kulturowego. Podręczniki ukazują tradycyjne ujęcie ról kobiet i mężczyzn w rodzinie, rodziny patriarchalne, który to obraz zupełnie nie przystaje do rzeczywistości. Również wizja szkoły jest raczej niedosiężnym ideałem niż rzeczywistym obrazem szkolnej rzeczywistości, podobnie jak wyidealizowana wizja historii Polski. Pomijane są pewne tematy uznawane przez autorów czy recenzentów podręczników jako zbyt trudne, zbędne czy niewychowawcze. Autorka postuluje, aby treści zawarte w podręcznikach były wiedzotwórcze, aktualne i przystające do realiów życia społecznego. Szyller zestawia obraz rzeczywistości prezentowany w podręcznikach z wiedzą i oczekiwaniami uczniów klas trzecich względem tychże (Szyller 2018b: 57-95). Uczniowie proponowali więcej zagadnień związanych z dziecięcymi doświadczeniami, opowiadań, w których bohaterami są rówieśnicy żyjący współcześnie. Wskazywali na humor i tajemniczość jako elementy wzbudzające zaciekawienie. Uczniowie chętnie widzieliby zadania rozwijające myślenie: zagadki, rebusy, wymagające dekodowania zaszyfrowanych informacji. Dostrzegają infantylność i banalność czytanek, szczególnie tych w klasie I, oraz powtarzanie treści w każdej kolejnej klasie (np. treści dotyczące pór roku). Zagadnienia, które wymieniali jako interesujące, a rzadko pojawiające się w szkolnych książkach, to sport, wynalazki, urządzenia, robotyka, minerały, państwa i miasta świata, historia, a nawet polityka.

Szkolni przyjaciele to cykl podręczników do klas I-III, przystosowanych do obowiązującej podstawy programowej Ministerstwa Edukacji Narodowej, jedna z trzech propozycji Wydawnictw Szkolnych i Pedagogicznych. WSiP rekomenduje książki jako rozbudzające ciekawość poznawczą i „poruszające istotne kwestie społeczno-wychowawcze" (inne zalety zostały pominięte jako nieistotne dla treści artykułu). Ze względu na specyfikę rozwojową uczniów klas I-III i propedeutyczny charakter kształcenia, autorzy podręcznika Szkolni przyjaciele położyli największy nacisk na wpajanie uczniom społecznych norm i wartości obowiązujących w szkole, rodzinie, środowisku lokalnym oraz całej społeczności ludzkiej. W cyklu opowiadań Zofii Staneckiej szkolny duszek Kalasanty zaznajamia dzieci z normami dobrego wychowania i zasadami obowiązującymi w szkole. W klasie III, oprócz konkretnych przykładów zachowań pozytywnych, coraz więcej jest tekstów bezpośrednio promujących preferowane z wychowawczego punktu widzenia cechy: obowiązkowy, wytrwały, kulturalny, prawdomówny, odważny. Postać Zawiszy Czarnego jako wzorca osobowego, nawiązanie do tradycji rycerskiej i hasło „Bądź rycerzem w swojej szkole” jest jednak mało zrozumiałe dla współczesnych uczniów.

Zasady i normy dotyczące relacji rodzinnych są licznie prezentowane we wszystkich analizowanych książkach. Zagadnienie to jest zawarte zarówno w opowiadaniach, jak i wierszach. Prawie wszystkie teksty ukazują rodzinę pełną, w której panuje miłość, 
zgoda, a rodzice są wsparciem dla dzieci, a jeżeli pojawiają się nieporozumienia, to dotyczą relacji między rodzeństwem. Wyjątek stanowi tekst Stowa odlatuja jak ptaki, ukazujący trudności w komunikacji między córką i matką po śmierci ojca. Pozostając przy społecznych wzorcach kulturowych, istotną pozycję zajmują altruizm i uwrażliwienie uczniów na potrzeby innych, krzywdę, jaka dotyka ludzi czy zwierzęta. Propaguje się wśród uczniów wolontariat, ukazując w opowiadaniu Wolontariusze akcję zbiórki karmy dla psów, czy w opowiadaniu Serce z piernika organizację przedstawienia dla domu seniora.

Wychowanie patriotyczne i obywatelskie znajduje szeroką reprezentację w tekstach prozatorskich i poetyckich podręcznika, od legendarnej historii Polski po różne teksty dotyczące II wojny światowej. W podręczniku do III klasy jest zamieszczona oś czasu od X wieku - chrztu Polski, po 1918 rok, co może być zaskoczeniem dla bardziej dociekliwych uczniów i rodzić pytania, co było po roku 1918. Bardzo dużo miejsca zajmuje tematyka odzyskania niepodległości w 1918 roku i budowanie państwowości przez Józefa Piłsudskiego. Patriotyzm budowany jest z wykorzystaniem wzorców osobowych wybitnych Polaków: Henryka Arctowskiego, Wandy Rutkiewicz oraz innych wymienionych w podstawie programowej. Majowe święta stają się asumptem do kształtowanie wartości takich jak demokracja, patriotyzm, szacunek dla kraju, odniesienie do wartości pracy i wspólnoty. Uczniowie poznają historię parlamentaryzmu w Polsce od Konstytucji 3 Maja po współczesne organy władzy.

Zgodnie z podejściem Janusza Gajdy do problematyki wychowania patriotycznego i obywatelskiego, oddziaływania edukacyjne powinny iść w dwóch kierunkach (por. Gajda 2018: 175-181). Jeden biegun to budowanie wartości patriotycznych, począwszy od patriotyzmu lokalnego, opartego na wiedzy o historii i teraźniejszości terenu, na którym się mieszka, dumy z osiągnięć ludzi z najbliższej okolicy oraz utożsamiania się z dziedzictwem kulturowym regionu. Drugi biegun odwołuje się do wartości uniwersalnych, wspólnych dla różnych kultur, wartościach humanizmu, sprzyja niwelowaniu barier kulturowych. W podręczniku edukacji wczesnoszkolnej poznanie innych kultur łączy się z ukazaniem zwyczajów szkolnych w odległych krajach (Iran, Japonia, Kanada, Chiny), ale także wskazanie trudności w dostępie do edukacji dziewczynek z niektórych kręgów kulturowych. Bardzo konwencjonalne i sztampowe podejście do innych kultur uwidacznia się poprzez zobrazowanie życia Aborygenów w Australii czy afrykańskiej biedy. Ale można też znaleźć interesujące podejście do budowania płaszczyzn wspólnotowych porozumienia międzykulturowego w opowiadaniu ukazującym podobieństwa w stylu życia, zainteresowaniach i działaniach chłopca z Polski i dziewczynki z Maroka, którzy kontaktują się przez Internet. Budowanie wspólnoty ogólnoludzkiej ukazuje też opowiadanie o zaproszeniu na Wigilię mieszkających w tym samym bloku Wietnamczyków. 
Podręcznik zapoznaje uczniów z dorobkiem kultury materialnej polskiej i światowej. Ukazuje przykłady architektury dawnej i współczesnej, sztukę użytkową, np. tkactwo (arras, krosna), hafciarstwo, ale także zawiera informacje o epistolografii, czy ciekawostki związane z odkryciami dokonywanymi przez naukowców, których praca porównywana jest do działań detektywów, np. w zakresie paleontologii czy kryptologii (powstanie maszyny szyfrującej Enigma). W podręczniku zamieszczone są obrazy mistrzów baroku, realizmu, impresjonizmu czy malarstwa abstrakcyjnego zarówno Polaków, jak i przedstawicieli innych narodów.

Szkolni przyjaciele wprowadzają uczniów w świat kodów kulturowych. Sporo tekstów poświęconych jest tradycji świąt Bożego Narodzenia i Wielkanocy, ale są też odwołania do symboliki i obchodów świąt państwowych, Dnia Edukacji Narodowej czy Dnia Bezpiecznego Internetu. Literatura dziecięca, będąca nośnikiem symboli kultury, jest reprezentowana m.in. przez baśnie J.H. Andersena, fragmenty Doktora Dolittle $\mathrm{H}$. Loftinga, czy inne lektury zaproponowane w podstawie programowej. W analizowanych książkach są też teksty odwołujące się do mitologii antycznej (Po nitce Ariadny, Fletnia Pana), czy jak w wierszu Kamelot N. Usenko do legend arturiańskich. W analizowanych książkach zamieszczone są też informacje o różnych sposobach komunikacji (alfabet Morse’a, telegraf, język Braille’a czy migowy), uświadamiające możliwość przekazu treści nie tylko poprzez tradycyjny kod mowy mówionej czy pisanej. Niewiele jest niestety pozytywnych przykładów wprowadzania uczniów w świat poezji, w większości wierszy dominuje dydaktyzm, a nie poetycka wizja świata.

\section{Podsumowanie}

Wychowanie do kultury i przez kulturę znajduje odzwierciedlenie zarówno w aktualnej podstawie programowej, jak i w cyklu podręczników edukacji wczesnoszkolnej Szkolni przyjaciele. Analizowany podręcznik zawiera pełny wachlarz wzorów kulturowych odnoszących się do systemu norm, wartości i zasad, które młode pokolenie powinno przejąć w ramach inkulturacji. W porównaniu do przytoczonych wcześniejszych analiz podstawy programowej i podręczników, widać zdecydowaną poprawę zarówno pod kątem odniesień do ponadczasowych, ogólnoludzkich wartości, jak i obrazu aktualnego świata. Nadal jednak świat ukazywany w podręcznikach jest wyidealizowany, ukazujący szczęśliwe dzieci w pełnych rodzinach, podczas gdy rzeczywistość daleka jest od tego obrazu. Zdecydowanie częściej w podręczniku można znaleźć teksty opiewające męstwo Polaków (od legionów Dąbrowskiego po II wojnę światowa) niż odniesienia do działań twórców kultury. Podręczniki zawierają informacje i zdjęcie obiektów kultury materialnej, ale jest to tylko wybór z szerokiego kontekstu kulturowego. Budowanie wiedzy o dorobku kulturowym opiera się na częstym 
obcowaniu z artefaktami, i to od nauczyciela będzie w znacznej mierze zależało, jakie przedmioty materialnego dorobku ludzkości uczniowie będą mieli możliwość poznawać. Edukacja kulturowa to nie tylko lekcje w klasie ukazujące bogactwo wytworów ludzi na przestrzeni wieków, ale uczestnictwo w wydarzeniach kultury lokalnej zarówno w formie biernej jako odbiorcy, jak i aktywnie jako współtwórcy przedsięwzięć kulturowych. „Kultura nie jest niezobowiązującym i odświętnym dodatkiem do codzienności, lecz stanowi czynnik formowania osobowości, mentalności zbiorowej(...)” (Bednarek, Repsch 2004: 7), stąd tak ważne już w klasach najmłodszych jest wychowywanie uczniów na wzorach kulturowych, uczenie rozumienia kodów kultury, wdrażanie do uczestnictwa i - w miarę dziecięcych możliwości - umożliwianie im tworzenia kultury.

\section{Bibliografia}

Bednarek S., Repsch E. (red.). (2004). Edukacja kulturowa dzieci i mtodzieży szkolnej. Koncepcje i propozycje Wrocław: Wydawnictwo DTSK Silesia.

Bogaj A. (1998). Dylematy przemian ksztatcenia ogólnego, [w:] I. Wojnar, J. Kubin (red.), Kultura-inspiracją ksztatcenia ogólnego, Warszawa: Dom Wydawniczy ELIPSA, s. $185-198$.

Encyklopedia pedagogiczna XXI wieku. Suplement. (2010) T. Pilch (red.), Warszawa: Wydawnictwo Akademickie „Żak”, s. 610-612.

Klus-Stańska D. (2009). Dyskursy pedagogiki wczesnoszkolnej, [w:] Pedagogika wczesnoszkolna - dyskursy, problemy, rozwiazania, Klus-Stańska D., Szczepska-Pustkowska M. (red.), Warszawa: Wydawnictwa Akademickie i Profesjonalne.

Kwieciński T., Śliwerski B. (2011). Pedagogika. Podręcznik akademicki, Warszawa: Wydawnictwo Naukowe PWN, t. 1.

Łobocki M. (2005). Teoria wychowania w zarysie, Kraków: Impuls.

Szyller A. (2018a). Ewaluacja podręczników zintegrowanych do edukacji wczesnoszkolnej. Perspektywa dorostych, Warszawa: Wydawnictwa Uniwersytetu Warszawskiego.

Szyller A. (2018b). Ewaluacja podręczników zintegrowanych do edukacji wczesnoszkolnej. Perspektywa dzieci, Warszawa: Wydawnictwa Uniwersytetu Warszawskiego.

Uniwersalne wartości kultury w edukacji i terapii (2012). I. Nowakowska-Kempna (red. nauk.), Kraków: Akademia Ignatianum-Wydawnictwo WAM,

Wojnar I. (2000). Humanistyczne intencje edukacji, Warszawa: Wydawnictwo Akademickie "Żak".

Zalewska E. (2009). Programy ksztatcenia i podręczniki szkolne w edukacji poczatkowej jako "wybór z kultury", [w:] Pedagogika wczesnoszkolna - dyskursy, problemy, rozwiazania, D. Klus-Stańska, M. Szczepska-Pustkowska M. (red.), Warszawa: Wydawnictwa Akademickie i Profesjonalne.

Podstawa programowa wychowania przedszkolnego i ksztatcenia ogólnego dla szkoty podstawowej z komentarzem. Wychowanie przedszkolne i edukacja wczesnoszkolna. (2017). Ośrodek Rozwoju Edukacji. Warszawa: Dobra Szkoła. 


\section{Netografia}

Jabłońska A.M. ( 2019). Wychowanie do kultury: przesztość i teraźniejszość, pytania i propozycje, „Seminare. Poszukiwania naukowe” t. 40, nr 3, s. 131-144. https://ojs.seminare. $\mathrm{pl} /$ index.php/seminare/article/view/384/400 [dostęp: 4.11.2020].

Pikała A.(2014). Edukacja kulturalna $w$ szkole - zatożenia i determinanty realizacji „Kultura i Wychowanie" rr 7/1 https://pedagogika.pl/wp-content/uploads/2017/07/KiW_ 07_01_2014-1.pdf [dostęp: 4.11.2020].

Tytko M.M.(2011). O problemach kultury plastycznej w edukacji, „Kultura i Wychowanie" $\mathrm{nr} 2 / 2$, s. 146-165, https://pedagogika.pl/wp-content/uploads/2017/07/ KiW_02_02_2011-2.pdf [dostęp: 4.11.2020].

Koschany R., Skórzyńska A. (red.). (2014). Edukacja kulturowa Podręcznik, Centrum Kultury ZAMEK http://cpe.poznan.pl/wp-content/uploads/2014/07/CPE_porecznik_interaktywny.pdf [dostęp: 4.11.2020].

Zwinogrodzka W. (2014). Kanon kultury i polityka kulturalna (debata) https://polskawielkiprojekt.pl/2014/06/kanon-kultury-i-polityka-kulturalnal[dostęp:2.11.2020] [dostęp: 3.02.2021]

\section{ADRES DO KORESPONDENCJI}

Sławomira Pusz

Uniwersytet Rzeszowski

e-mail: spusz@ur.edu.pl 